ОСОБЛИВОСТІ ПРОФЕСІЙНОЇ ПІДГОТОВКИ ОФІЦЕРІВ ДПСУ НА ОПЕРАТИВНО-ТАКТИЧНОМУ РІВНІ ВІЙСЬКОВОЇ ОСВІТИ

\title{
FEATURES OF PROFESSIONAL TRAINING OF OFFICERS OF THE STATE BORDER GUARD SERVICE OF UKRAINE AT THE OPERATIONAL AND TACTICAL LEVEL OF MILITARY EDUCATION
}

УДК 355.233.1: 355.457

DOI https://doi.org/10.32843/2663-

$6085 / 2021 / 33-1.3$

\section{Білявець С.Я.}

докт. пед. наук

заступник ректора (проектор)

3 навчальної та наукової роботи

Національної академії Державної

прикордонної служби України імені

Богдана Хмельницького

\begin{abstract}
Стаття присвячена проблемі підвищення якості професійної підготовки офріцерів прикордонної служби на оперативно-тактичному рівні. Розкрито актуальність запропонованої проблеми на основі аналізу статусу прикордонного відомства як соціального інституту українського суспільства. Виокремлено проблематику сучасної профресійної підготовки офріцерів-прикордонників оперативно-тактичного рівня. Проаналізовано різноманітні наукові джерела від загального до часткового рівнів викладу проблеми. Охарактеризовано зміст ключових особливостей зазначеної вище профресійної підготовки, таких як виокремлення низки спеціальностей; розроблення освіт ньо-профресійних програм для підготовки офріцерів-прикордонників за певними спеціальностями (визначено зміст загальних фрахових та вибіркових компетентностей, програмні результати навчання, які враховують вимоги щодо євроінтеграційного курсу України, інтегрованого управління кордонами, готовність та здатність до виконання професійних обов'язків на посаді керівника органу охорони державного кордону); проєктування навчальних планів, що містять блоки обов'язкового, військово-прикордонного та вибіркового компонентів (зміст навчальних дисциплін повинен забезпечити ірозвиток, і формування знань, умінь та навичок, досвіду, здатностней задля забезпечення діяльності регіонального управління ДПСУ та механізованої бригади); формулювання вимог до науково-педагогічних працівників, котрі є відповідальними за якість підготовки офріцерів оперативнотактичного рівня (підвищення педагогічноі майстерності, сорормованості високого рівня профресійної компетентності, відповідності базової академічної освіти тим навчальним дисциплінам, які викладають офріцерам оперативно-тактичного рівня, володіння оперативною інфрормацією щодо фрункціонування ДПСУ, тобто відображення у змісті навчальних дисциплін тісного зв'язку між теорією та практикою); врахування у змісті професійної підготовки офрічерів-тактичного рівня сучасних загроз та викликів.
\end{abstract}

Ключові слова: офрічери-прикордонники професійна підготовка, прикордонна служба, оперативно-тактичний рівень, вища військова освіта.

The article is devoted to the problem of improving the quality of professional training of border guards at the operational and tactical level. The urgency of the proposed problem is revealed based on the analysis of the status of the border department as a social institution of the Ukrainian society. The problems of modern professional training of border guards of operational and tactical level are singled out. Various scientific sources in the direction from the general to the partial level of the problem are analyzed. Describes the content of the key features of the above training: the selection of a number of specialties; development of educational and professional programs for the training of border guards in certain specialties (defined content of general, professional and selective competencies, program learning outcomes that take into account the requirements of the European integration course of Ukraine, integrated border management, readiness and ability to perform professional duties head of the state border protection body); designing curricula that contain blocks of mandatory, military-border and elective components (the content of disciplines should ensure the development and formation of knowledge, skills, experience, abilities to ensure the activities of the regional department and mechanized brigade); requirements are formulated for scientific and pedagogical workers who are responsible for the quality of training of operational and tactical level officers (improvement of pedagogical skills, high level of professional competence, compliance of basic academic education with those disciplines taught to operational and tactical level officers, possession of operational information on functioning is reflection in the content of academic disciplines of the close connection between theory and practice); taking into account in the content of professional training of officerstactical level of modern threats and challenges. Key words: border guards, professional training, border service, operational and tactical level, higher military education.
Постановка проблеми у загальному вигляді. Особистість, котра створює соціальну спільноту, що $€$ основою соціуму, свідомо та несвідомо потребує задоволення екзистенційних потреб. Сутність цих потреб полягає у забезпеченні особистої та групової потреби у безпечному існуванні. У зв'язку з цим людина створила відповідні соціальні інститути, а саме правовий, політичний, правоохоронний та військовий. В українській соці- альній системі вартий уваги інститут, який виконує фрункції щодо охорони та захисту державного кордону, а саме прикордонна служба. Державна прикордонна служба України (далі - ДПСУ) належить до фрундаментальних утворень суспільства, тобто ефективність їі фрункціонування впливає на стабільність соціальної системи, її цілісність, взаємозв'язок з іншими соціальними інститутами тощо. Для забезпечення успішних перетворень у 
ДПСУ необхідно підготувати такі офріцерські кадри, які зможуть це завдання виконати.

Аналіз останніх досліджень і публікацій. Проблема підготовки офріцерів ДПсу на оперативно-тактичному рівні випливає із загальнодержавної проблеми якості підготовки майбутніх фрахівців будь-якої галузі в Україні. У цьому контексті проаналізовано наукові праці Н. Бібік [2], О. Глузмана [3], О. Овчарук [9], предметом дослідження яких були сучасні педагогічні технології у вищій освіті, реалізація компетентісного підходу, проблеми реформування змісту сучасної вищої освіти в Україні.

Необхідно зазначити, що військова вища освіта в Україні має потужний науковий фрундамент, що засвідчують роботи Л. Балагур (підготовка майбутніх офріцерів-прикордонників до управління основними підрозділами охорони державного кордону) [1]; О. Гончаренка (аналіз західної парадигми формування особистості військового професіонала) [4]; М. Голик (дослідження проблем фрормування вищої військової освіти в Україні у перші роки незалежності XX століття) [5]; Ю. Дем'янюк (формування військово-організаторських умінь у майбутніх ооріцерів ДПСУ) [6]; О. Діденко (психолого-педагогічні чинники профресійного навчання офріцерів управління органами охорони державного кордону) [7]; С. Дяков (методичні засади тактико-спеціальної підготовки майбутніх офіцерів інженерних військ) [8]. Список науковців, які вивчали різні проблеми, дотичні до вищої військової освіти, є невичерпним.

Виділення не вирішених раніше частин загальної проблеми. Незважаючи на наявність монографрій, дисертацій та численних публікацій 3 питань підготовки офріцерів ДПСУ, відсутні напрацювання, присвячені аналізу змісту оперативнотактичної підготовки офріцерів-прикордонників.

Мета статті. Метою статті $€$ аналіз особливостей профресійної підготовки офріцерів Державної прикордонної служби України на оперативно-тактичному рівні військової освіти.

Виклад основного матеріалу. Для розуміння змісту сформульованої у статті проблеми необхідно проаналізувати особливості професійної діяльності офріцерів ДПСУ на оперативно-тактичному рівні.

Зміст професійної діяльності офріцерів дПСУ оперативно-тактичного рівня обумовлений ії фрункціями, що відображені у законодавчих актах із визначеними професійними завданнями щодо охорони та захисту державного кордону.

Основним законодавчим документом $€$ Закон України «Про державний кордон України», у якому чітко сорормульовано зміст профресійної діяльності прикордонників, їх завдання [10]. У професійній підготовці офріцерських кадрів оперативно-тактичного рівня усе це враховано.
1) Виокремлено спеціальності «Безпека державного кордону», «Філологія», «Право», «Правоохоронна діяльність», «Автомобільний транспорт», «Військове управління», «Національна безпека», «Публічне управління та адміністрування». Вибір спеціальностей для офріцерів оперативно-тактичного рівня зумовлений певними фракторами, такими як вступ до магістратури офріцерів 3 уже сорормованим професійним досвідом; оперативно-тактичний рівень, що є другим освітнім рівнем, який зобов'язаний забезпечити оперативно-тактичний рівень військового управління в ДПСУ.

2) Розроблено освітньо-профресійні програми (далі-ОПП) для підготовки офріцерів-прикордонників за вищезазначеними спеціальностями. В ОПП визначено зміст загальних, фрахових та вибіркових компетентностей, програмні результати навчання, які враховують вимоги щодо євроінтеграційного курсу України, інтегрованого управління кордонами, готовність та здатність до виконання професійних обов'язків на посаді керівника органу охорони державного кордону. Розвиток усіх компетентностей офріцерів оперативно-тактичного рівня вимагає використання досвіду Північно-Атлантичного Альянсу (НАТО) та Європейського Союзу у сорері охорони кордону, інновацій у педагогіці, управлінні, законодавстві тощо.

3) Спроєктовано навчальні плани, що містять блоки обов'язкового, військово-прикордонного та вибіркового компонентів. Офріцери-прикордонники оперативно-тактичного рівня є управлінцями на посадах органів охорони державного кордону, тому зміст навчальних дисциплін повинен забезпечити і розвиток, і фрормування знань, умінь та навичок, досвіду, здатності задля забезпечення діяльності регіонального управління ДПСу та механізованої бригади. У навчальних планах усіх спеціальностей запропоновано сучасні управлінські навчальні дисципліни (наприклад, «Наукові основи управління»), військово-прикордонні навчальні дисципліни («Інформаційно-аналітичне забезпечення оперативно-службової діяльності» тощо), вибіркові навчальні дисципліни (зокрема, «Проєктний менеджмент»).

4) Сорормульовано вимоги до науково-педагогічних працівників, котрі $€$ відповідальними за якість підготовки офріцерів оперативно-тактичного рівня. Сучасна освітня система перебуває у перехідному стані, і це проблема не лише України. Численні фрактори - від фрормування Четвертої промислової революції до пандемії - вимагають переосмислення освітньої парадигми. 3 огляду на це роль викладача також зазнає у майбутньому змін. Навіть у сучасній вищій військовій освіті за доступності інформації та фрормування нового технолого-інорормаційного простору науково-педагогічні працівники здійснюють передачу слухачам 
(офріцерам оперативно-тактичного рівня) свого безцінного професійного та життєвого досвіду та власного суб'єктивного погляду на ті чи інші проблеми у світі. ДПСУ як державний інститут відчуває вплив сучасних технологій та окремих досягнень в інформаційно-комунікативній сорері, тому науково-педагогічним працівникам у вищому військовому навчальному закладі ДПСУ, а саме Національній академії ДПСУ, скеровані запити щодо підвищення їх педагогічної майстерності, сорормованості високого рівня профресійної компетентності, відповідності базової академічної освіти тим навчальним дисциплінам, що викладають офріцерам оперативно-тактичного рівня. Ще однією важливою вимогою до науково-педагогічних кадрів прикордонної академії $€$ володіння оперативною інфрормацією щодо фрункціонування ДПСУ, тобто відображення у змісті навчальних дисциплін тісного зв'язку між теорією та практикою. На особливу увагу заслуговує проблема запровадження в освітній процес освітніх інновацій. Як засвідчує досвід західної освітньої системи у сфері підготовки фрахівців сектору безпеки та оборони, провідною тенденцією є збільшення частки практичних навчальних занять, що дають змогу удосконалювати вміння та навички фрахівця шляхом фрормування в них навіть рівня так званої професійної інтуїції та критичного системного мислення.

5) Останнім, проте не менш важливим фрактором $€$ врахування у змісті професійної підготовки офріцерів-тактичного рівня сучасних загроз та викликів, зокрема локалізації на Сході України військового конфлікту. Такий стан речей в історичному розвитку сучасної України справив відчутний вплив на сприйняття правоохоронних та військових орормувань у суспільстві, транссрормацію громадянського суспільства і, відповідно, перегляд змісту та підходів до реалізації вищої військової освіти в Україні.

Загалом необхідно зазначити, що соціальні, інорормаційні та інтелектуальні розриви між поколіннями в сучасному світі скоротились, отже, пріоритетним завданням професійної підготовки майбутнього фрахівця, зокрема офріцера-прикордонника оперативно-тактичного рівня, $є$ фрормування в нього нового стилю мислення, здатності до гнучкої взаємодії з усіма суб'єктами профресійного середовища, до сприйняття, аналізу та використання інфрормації.

Висновки. Таким чином, особливості профресійної підготовки офріцерів-прикордонників оперативно-тактичного рівня зумовлені специфікою їх профресійної діяльності та трансформаціями в сучасному суспільстві. Задля розширення кола наукових пошуків варто звернути увагу на подолання консерватизму у вищій військовій освіті як характеристики пострадянської освітньої парадигми, окреслення чітких стратегій щодо впровадження інновацій в освітній процес тощо.

\section{БІБЛІОГРАФІЧНИЙ СПИСОК:}

1. Балагур Л. Підготовка майбутніх офріцерів-прикордонників до управління основними підрозділами охорони державного кордону : дис. ... канд. пед. наук : спец. 13.00.04. Хмельницький, 2015. 227 с.

2. Бібік Н., Єрмаков І., Овчарук О. Компетентнісна освіта - від теорії до практики. Київ : Плеяда, 2005. $120 \mathrm{c}$.

3. Глузман О. Базові компетентності: сутність та значення в життєвому успіху особистості. Педагогіка і психологія. 2009. № 2 (63). С. 51-60.

4. Гончаренко О. Західна парадигма фрормування особистості військового професіонала (соціальнофрілософський аналіз) : авторефр. дис. ... канд. фрілософ. наук : спец. 09.00.03 «Соціальна фрілософрія та фрілософрія історії» ; Харківський університет Повітряних сил імені Івана Кожедуба. Харків, 2008. 20 с.

5. Голик М. Формування вищої військової освіти в Україні (1992-1998рр.) : автореф. дис. ... канд. іст. наук : спец. 20.02.22 «Військова історія»; Національний університет «Львівська політехніка». Львів, 2000. 20 c.

6. Дем'янюк Ю. Формування військово-організаторських умінь у майбутніх офріцерів Державної прикордонної служби України : автореф. дис. ... канд. пед. наук : спец. 13.00.04 «Теорія і методика професійної освіти» ; Національна академія Державної прикордонної служби України ім. Богдана Хмельницького. Хмельницький, 2010. 20 с.

7. Діденко О. Психолого-педагогічні чинники професійного навчання офріцерів управління органів охорони державного кордону. Науковий вісник Чернівецького університету. 2015. Вип. 738 : Педагогіка та психологія. С. 37-44.

8. Дяков С. Методичні засади тактико-спеціальної підготовки майбутніх офріцерів інженерних військ : автореф. дис. .... канд. пед. наук : спец. 13.00.02 «Теорія та методика навчання (загальновійськові та військово-спеціальні дисципліни») ; Національна академія Державної прикордонної служби України ім. Б. Хмельницького. Хмельницький, 2010. 20 с.

9. Компетентнісний підхід у сучасній освіті: світовий досвід та українські перспективи : колективна монограсрія / заг. ред. О. Овчарук. Київ : К.І.С, 2004. 112 c.

10. Про Державну прикордонну службу України : Закон України від 3 квітня 2003 р. № 661-IV. Відомості Верховної Ради України. 2003. № 27. Ст. 208. Зі змінами ; ост. ред. 9 черв. 2013 р. 